\title{
KARAKTERISASI SENSORI KOPI ROBUSTA DAMPIT: KAJIAN PUSTAKA
}

\section{Sensory Characterization of Dampit Robust Coffee: Literature Review}

\author{
Medina Alia Rahmawati*, Kiki Fibrianto \\ Jurusan Teknologi Hasil Pertanian, FTP Universitas Brawijaya Malang \\ Jl. Veteran, Malang 65145 \\ *Penulis Korespondensi: medinaalia.r@gmail.com
}

\begin{abstract}
ABSTRAK
Kopi merupakan salah satu hasil perkebunan yang memiliki nilai ekonomis yang tinggi. Indonesia merupakan negara eksportir kopi dan Kabupaten Malang adalah salah satu daerah penghasil kopi dengan produk unggulan kopi robusta Dampit. Kualitas seduhan kopi ditentukan oleh beberapa hal, antara lain teknik penyeduhan, suhu, dan lama waktu. Teknik penyeduhan terbagi menjadi imersi dan drip brewing. Drip brewing merupakan teknik penyeduhan yang bekerja dengan prinsip melewatkan air penyeduh satu kali ke dalam tumpukan bubuk kopi yang terdapat pada saringan, contohnya adalah woodneck drip pot. Imersi merupakan teknik merendam bubuk kopi dengan air di sebuah wadah, contohnya adalah café solo. Atribut sensori yang terdapat pada kopi antara lain adalah aroma, rasa, flavor, mouthfeel, dan aftertaste.
\end{abstract}

Kata kunci: Café Solo, Kopi Robusta Dampit, QDA, Woodneck Pot Drip

ABSTRACT

Coffee is one of the crops that has high economic value. Indonesia is a coffee exporter country and Malang is one of the coffee producing regions with Dampit robusta coffee as superior product. Coffee brewing quality is determined by several things, including brewing techniques, temperature, and time. Brewing techniques are divided into immersion and drip brewing. Drip brewing is a brewing technique that works by the principle of passing one brewing water into a pile of coffee powder contained in a sieve, for example a woodneck drip pot. Immersion is a technique of soaking coffee powder with water in a container, for example is a solo café. The sensory attributes found in coffee include aroma, taste, flavor, mouthfeel, and aftertaste.

Keywords: Café Solo, Dampit Robust Coffee, QDA, Woodneck Pot Drip

\section{PENDAHULUAN}

Minuman kopi seduh merupakan salah satu minuman yang digemari oleh masyarakat dunia. Menurut International Coffee Organization, pada tahun 2016-2017 konsumsi kopi oleh masyarakat dunia meningkat sebanyak $1.9 \%$ dari periode 2015/2016. Kopi juga merupakan salah satu hasil perkebunan yang memiliki nilai ekonomis yang tinggi. Berdasarkan data Direktorat Jenderal Perkebunan, hasil produksi kopi di Indonesia sejak tahun 2011 hingga 2016 selalu di atas 600 ribu ton. Indonesia juga merupakan negara eksportir terbanyak kedua setelah Brazil dengan angka ekspor sebanyak 27000kg (ICO, 2017). Pada tahun 2016, angka produksi kopi Indonesia mencapai total 662939 ton dan Jawa Timur berkontribusi sebesar 7.38\% dengan ratarata produksi 35814 ton per tahun. Salah satu kabupaten penghasil kopi di Jawa Timur adalah Kabupaten Malang dengan salah satu produk unggulan kopi robusta Dampit. 


\section{Kopi}

Kopi merupakan salah satu tanaman perkebunan yang memiliki ekonomis tinggi dan sudah lama dibudidayakan. Nama kopi berasal dari nama kota Kaffa di tenggara Ethiopia, di mana kopi pertama kali ditemukan. Ada sejarah lain yang menyatakan kata kopi berasal dari kata "kuvvah" yang berarti "kekuatan", karena kopi dikenal dapat mencegah kantuk (Küçükkömürler dan Özgen, 2009). Tanaman kopi merupakan spesies tanaman pohon yang termasuk dalam family Rubiaceae dan genus Coffea. Sistematika tanaman kopi menurut Aditya (2015), adalah sebagai berikut, Kingdom: Plantae, Sub kingdom: Trachebionta, Divisi: Magnoliophyta, Kelas: Magnolipsida, Sub Kelas: Asteridae, Ordo: Rubiceae, Genus: Coffea, Spesies: Coffea spp.

Tabel 1 SNI Syarat Mutu Uji Kopi Bubuk

\begin{tabular}{|c|c|c|c|c|}
\hline \multirow[t]{2}{*}{ No. } & \multirow[t]{2}{*}{ Kriteria Uji } & \multirow[t]{2}{*}{ Satuan } & \multicolumn{2}{|c|}{ Persyaratan } \\
\hline & & & 1 & II \\
\hline 1 & Keadaan: & & & \\
\hline 1.1 & $\mathrm{Bau}$ & - & Normal & Normal \\
\hline 1.2 & Rasa & - & Normal & Normal \\
\hline 1.3 & Warna & - & Normal & Normal \\
\hline 2 & Air & $\% \mathrm{~b} / \mathrm{b}$ & Maks. 7 & Maks. 7 \\
\hline 3 & Abu & $\% \mathrm{~b} / \mathrm{b}$ & Maks.5 & Maks. 5 \\
\hline \multirow[t]{2}{*}{4} & Kealkalian abu & mlxN.NaOH & $57-64$ & Min. 35 \\
\hline & & $100 \mathrm{~g}$ & & \\
\hline 5 & Sari Kopi & $\% \mathrm{~b} / \mathrm{b}$ & $20-36$ & Maks. 60 \\
\hline 6 & Kafein (anhidrat) & $\% \mathrm{~b} / \mathrm{b}$ & $0.9-2$ & $0.45-2$ \\
\hline 7 & Bahan - bahan Lain & - & $\begin{array}{l}\text { Tidak boleh } \\
\text { ada }\end{array}$ & Boleh ada \\
\hline 8 & Cemaran logam: & & & \\
\hline 8.1 & Timbal (Pb) & $\mathrm{mg} / \mathrm{kg}$ & Maks 2.0 & Maks 2.0 \\
\hline 8.2 & Tembaga (Cu) & $\mathrm{mg} / \mathrm{kg}$ & Maks 30.0 & Maks 30.0 \\
\hline 8.3 & Seng $(Z n)$ & $\mathrm{mg} / \mathrm{kg}$ & Maks 40.0 & Maks 40.0 \\
\hline 8.4 & Timah (Sn) & $\mathrm{mg} / \mathrm{kg}$ & $\begin{array}{l}\text { Maks } 40.0 \text { / } \\
250.0^{*}\end{array}$ & $\begin{array}{l}\text { Maks } 40.0 \text { / } \\
250.0^{*}\end{array}$ \\
\hline 8.5 & Raksa (Hg) & $\mathrm{mg} / \mathrm{kg}$ & Maks 0.03 & Maks 0.03 \\
\hline 9 & Arsen (As) & $\mathrm{mg} / \mathrm{kg}$ & Maks 1.0 & Maks 1.0 \\
\hline 10 & Cemaran Mikroba & & & \\
\hline 10.1 & Angka Lempeng Total & Koloni/g & Maks. $10^{6}$ & Maks $10^{6}$ \\
\hline 10.2 & Kapang & Koloni/g & Maks $10^{4}$ & Maks $10^{4}$ \\
\hline
\end{tabular}

Sumber: Badan Standarisasi Nasional (2004)

Alur produksi kopi meliputi pengolahan awal, pengupasan, sortasi, pengemasan dan penggudangan, penyangraian, penggilingan, dan penyeduhan. Secara umum, teknik pengolahan kopi terdiri atas pengolahan kering (natural), pengolahan basah (fullwashed), dan pengolahan semi basah (semi-wash). Penyangraian kopi dibedakan menjadi tiga jenis yaitu light roast, medium roast, dan dark roast. Teknik penyeduhan pada kopi secara umum dibedakan menjadi dua jenis yaitu drip dan imersi. Metode imersi dilakukan dengan merendam bubuk kopi dengan air panas dalam suatu wadah / bejana. Teknik penyeduhan tetes hanya melewatkan air penyeduh satu kali ke dalam tumpukan bubuk kopi yang terdapat pada saringan (Mulato dan Suharyanto, 2012).

Kualitas penyeduhan kopi dipengaruhi oleh beberapa hal, antara lain formulasi, ukuran partikel, suhu air penyeduhan, pengadukan, dan kualitas air penyeduham. Rendemen senyawa terlarut yang memberikan seduhan kopi ideal berkisar antara 18$22 \%$ dari \% total senyawa yang bisa terlarut dari dalam bubuk kopi. Ukuran partikel 
mempengaruhi senyawa kimia yang terlarut, semakin kecil ukuran partikel, maka luas permukaannya juga akan semakin besar sehinga kontak air dan biji kopi dapat terjadi semakin sering. Suhu yang ideal untuk menyeduh kopi adalah $90-96^{\circ} \mathrm{C}$ (Specialty Coffee Association of America, 2016). Pengadukan merupakan suatu tindakan paksaan secara manual maupun mekanis agar kontak antar semua partikel bubuk kopi dan air penyeduh berlangsung secara intensif dan uniform. Komponen kualitas air penyeduh yang dapat berpengaruh pada citarasa seduhan kopi, proses penyeduhan, dan kinerja alat penyeduh.

\section{Teknik Penyeduhan Kopi}

Penyeduhan kopi merupakan proses kontak bubuk kopi dengan air yang akan menghasilkan larutan kopi yang dapat diminum. Secara umum, teknik penyeduhan terbagi menjadi 2, yaitu imersi/steeping dan perkolasi/drip.

Metode imersi dilakukan dengan merendam bubuk kopi dengan air panas dalam suatu wadah / bejana. Kontak antara air penyeduh dan bubuk kopi yang berlangsung selama keduanya berada di dalam bejana berlangsung dalam waktu yang relatif lama. Seduhan merupakan suspense kopi yang terdiri atas larutan kopi dan padatan tidak terlarut. Padatan terlarut akan mengendap dan terpisah dari larutan dalam bentuk ampas (Mulato dan Suharyanto, 2012).

Contoh alat seduh yang menggunakan prinsip ini adalah Cafe solo,. Alat ini merupakan alat penyeduh kopi yang terdiri atas bejana kaca yang terselimuti dengan semacam kain dan dilengkapi dengan penyaring yang terbuat dari logam. Bubuk kopi yang akan diseduh dimasukkan ke dalam bejana kaca, kemudian air dengan rentang suhu $90-96^{\circ} \mathrm{C}$ dialirkan ke dalamnya dan setelah itu diaduk dengan arah putaran searah. Larutan kemudian larutan dibiarkan selama 3-4 menit. Seduhan kopi dituangkan melalui filter logam untuk mencegah masuknya ampas kopi ke dalam gelas (Evasolo, 2015). Seduhan kopi yang dihasilkan oleh alat ini cenderung pekat dan berwarna cokelat kehitaman.

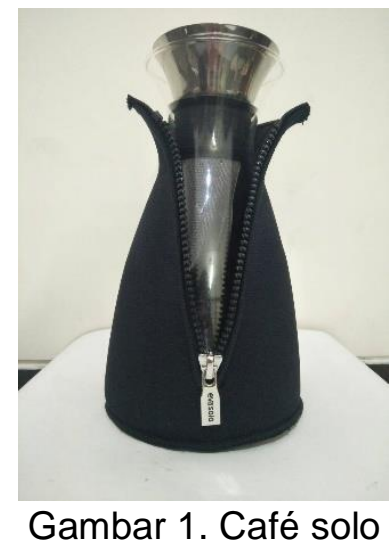

Teknik penyeduhan tetes hanya melewatkan air penyeduh satu kali ke dalam tumpukan bubuk kopi yang terdapat pada saringan. Bubuk kopi diletakkan di dalam corong yang dilengkapi dengan penyaring. Bahan saringan dapat terbuat dari kertas, logam, kain, maupun plastik. Air seduhan dituang secara perlahan-lahan ke dalam corong hingga air mengenang di atas tumpukan bubuk kopi. Air penyeduh akan meresap secara perlahan ke dalam bubuk dan melarutkan senyawa pembentuk citarasa kopi di dalam tumpukan bubuk kopi dan kemudian menembus pori-pori saringan. Larutan kopi kemudian akan menetes dan ditampung di dalam sebuah bejana seperti gelas, cangkir, atau poci. Ampas tertinggal dalam saringan (Mulato dan Suharyanto, 2012).

Contoh teknik penyeduhan yang termasuk ke dalam drip brewing adalah woodneck drip pot. Alat ini merupakan alat penyeduh kopi yang terdiri atas bejana kaca yang 
dilengkapi dengan penyaring yang terbuat dari kain flannel. Bubuki kopi dimasukkan ke dalam penyaring flannel, kemudian dialirkan air dengan suhu $90-96^{\circ} \mathrm{C}$ melewati bubuk dan filter. Seduhan kopi tanpa ampas akan tertampung di dalam bejana kaca. Seduhan kopi yang dihasilkan alat ini cenderung berwarna cokelat dan tidak terlalu pekat.

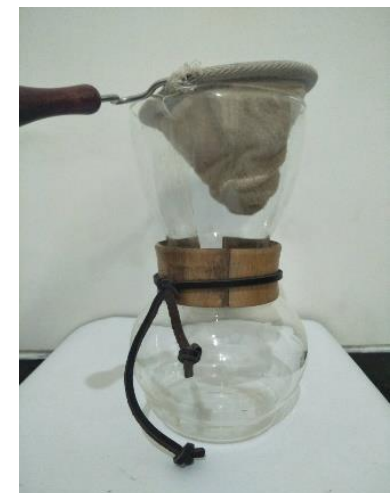

Gambar 2. Woodneck Drip Pot

\section{Antioksidan dan Total Fenol}

Antioksidan adalah senyawa yang dapat menghambat reaksi oksidasi dengan cara mengikat molekul yang sangat reaktif dan radikal bebas (Setiyaningrum, 2013). Biji kopi secara alami mengandung senyawa antioksidan jenis polifenol yang terdiri atas asam fenolat yang merupakan penyusun utama dan flavonoid sebagai penyusun minor (Mulato, 2012). Sedangkan komponen antioksidan lainnya, melanoidin merupakan senyawa yang dihasilkan saat penyangraian biji.

Senyawa fenolik pada tanaman disintesis untuk bertahan pada tekanan ekologikal dan fisiologi seperti serangan patogen dan serangga, radiasi UV, dan luka. Struktur dasar dari senyawa fenolik adalah cincin aromatik yang mengandung satu atau lebih gugus hidroksil. Senyawa fenolik pada tanaman diklasifikasikan berdasarkan jumlah unit fenol dalam molekul menjadi senyawa fenol sederhana dan polifenol (Khoddami, 2006).

\section{Atribut Sensori pada Kopi}

Tujuan dari evaluasi sensori adalah untuk mengetahui penerimaan konsumen, maka uji organoleptik menggunakan panelis (pencicip yang telah terlatih) yang dianggap paling peka dan sering digunakan untuk menilai mutu jenis makanan untuk mengukur daya simpannya. pangan. Aroma makanan adalah reaksi dari makanan yang dapat mempengaruhi konsumen sebelum menikmati makanan dengan membau makanan tersebut. Flavor merupakan atribut dari makanan, minuman, dan bumbu-bumbuan, yang dihasilkan dari rangsangan semua indera ketika makanan melalui saluran makanan dan pernapasan, terutama rasa dan bau. Rasa/taste merupakan sensasi yang dihasilkan oleh makanan dan komponen kimia lain ketika merangsang receptor dalam indera perasa pada lidah. Tekstur makanan adalah hasil dari respon tactile sense terhadap bentuk rangsangan fisik ketika terjadi kontak antara bagian dalam rongga mulut dan makanan (Sari dan Yohana, 2015). Pada kualitas seduhan kopi, tekstur didefinisikan sebagai densitas dan viskositas larutan dan sering disebut sebagai 'body'.

\section{SIMPULAN}

- Teknik seduhan, suhu, ,dan lama waktu penyeduhan berpengaruh terhadap atribut sensori kopi robusta dampit

- Secara umum, atribut sensori kopi robusta dampit dengan teknik seduhan woodneck dip pot memiliki atribut yang lebih bervariasi dibandingkan café solo. 


\section{DAFTAR PUSTAKA}

Aditya, I. 2015. Kajian kandungan kafein kopi bubuk, nilai ph dan karakteristik rasa dan aroma seduhan kopi jantan (pea berry coffee) dan betina (flat beans coffee) jenis arabika dan robusta. Skripsi. Universitas Udayana. Bali

Badan Standarisasi Nasional. 2004. Kopi bubuk. SNI 01-3542-2004

Evasolo, Inc. 2015. Guidelines for Brewing with a Cafe solo. http://evasolo.com/ Tanggal akses: 03/03/2018

International Coffee Organization. 2016. World coffee consumption. http://www.ico.org/ Tanggal akses: 07/10/2017

Khoddami, A., Wilkes, M., Roberts, T. 2006. Techniques for analysis of plant phenolic compounds. Molecule. 18:2, 2328-75

Küçükkömürler dan Özgen. 2009. Coffee and turkish coffee culture. Pakistan Journal of Nutrition 8:10, 1693-1700

Mulato, Sri., Suharyanto, Edi. 2012. Kopi, seduhan, dan kesehatan. Jember: Pusat Penelitian Kopi dan Kakao Indonesia Referensi

Specialty Coffee Association of America. 2016. Cupping water temperatur. http://www.scaa.org/ . Tanggal akses: 17/01/2018

Sari, K. Yohana, W. 2015. Tekstur makanan: sebuah bagian dari food properties yang terlupakan dalam memelihara fungsi kognisi. Makassar Dent J 2015; 4:6, 184-189

Setiyaningrum, Z. 2013. Aktivitas antiradikal dpph dan kadar fenolik dari ekstrak gambir (Uncaria gambir roxb) menggunakan metode maserasi dan soxhlet. Skripsi. Universitas Muhammadiyah Surakarta. Surakarta 